\title{
New contributions to the entrepreneurial theory of social and cultural change
}

\author{
Vicente Moreno Casas ${ }^{I}$ (D0000-0003-1194-4851
}

Loyola University, Dos Hermanas, Seville, Spain

\begin{abstract}
This paper combines the theoretical framework developed by Coyne and Boettke (2009) about an entrepreneurial theory of social and cultural change, with the contributions of Huerta de Soto (2010) about the impossibility of economic calculation in socialism. With this synthesis, the entrepreneurial theory of social and cultural change is reinforced to (1) refute any political action aimed to achieve social and cultural changes, and (2) to claim the entrepreneur as the driving force of all social phenomena. The paper concludes that, as in the market sphere, the government cannot effectively implement policies oriented to social and cultural change, since it cannot acquire the knowledge necessary to plan society and social relationships.
\end{abstract}

Keywords: Entrepreneurship, social and cultural change, knowledge, economic calculation, social bond.

\footnotetext{
${ }^{\mathrm{I}}$ Economics student at Loyola University, Spain. Interested in Austrian Economics and its connection with Feminist Economics and sociology. Email: vimoca1999@gmail.com
} 


\section{Novas contribuições para a teoria empresarial da mudança social e cultural}

Resumo: Este artigo alia o referencial teórico, desenvolvido por Coyne e Boettke (2009) sobre a teoria empresarial da mudança social e cultural, às contribuições de Huerta de Soto (2010), sobre a impossibilidade de cálculo econômico no socialismo. Com esse resumo, a teoria empresarial de mudança social e cultural é reforçada para (1) refutar qualquer ação política que objetiva alcançar as mudanças sociais e culturais, e (2) para ter o empreendedor como a força motriz de todo o fenômeno social. O artigo conclui que, assim como na esfera do mercado, o governo não pode implementar políticas orientadas à mudança social e cultura efetivamente, uma vez que ele não consegue adquirir o conhecimento necessário para planejar a sociedade e as relações sociais.

Palavras-chaves: Empreendedorismo, mudança social e cultural, conhecimento, cálculo econômico, laço social.

\section{Nuevas contribuciones a la teoría empresarial del cambio sociocultural}

Resumen: Este trabajo combina el marco teórico desarrollado por Coyne y Boettke (2009) sobre una teoría empresarial del cambio sociocultural, con las contribuciones de Huerta de Soto (2010) sobre la imposibilidad del cálculo económico en el socialismo. Con esta síntesis, la teoría empresarial del cambio sociocultural es reforzada para (1) refutar cualquier acción dirigida a conseguir cambios socioculturales y (2) para destacar al empresario como la fuerza motora de todos los fenómenos sociales. El trabajo concluye que, al igual que en el mercado, el gobierno no puede implementar políticas orientadas al cambio sociocultural efectivamente, ya que no puede hacerse con el conocimiento necesario para planificar la sociedad y las relaciones sociales.

Palabras clave: Función empresarial, cambio sociocultural, conocimiento, cálculo económico, tejido social. 


\section{Introduction}

A great deal has been written about social and cultural change, and how entrepreneurs can influence in the social process. For this purpose, many scholars talk about political entrepreneurship, and believe that some individuals with entrepreneurial features can act within governments in order to attain social and cultural changes. However, some assert that the State can become an entrepreneur and act entrepreneurially to shift culture. In all of them, they support government intervention and its coercive nature. Nonetheless, many Austrians have addressed this topic. McCaffrey and Salerno (2011) adapted the ideas of Austrian ${ }^{1}$ and liberal thinkers to redefine the concept of political entrepreneurship, underlining its coercive and violent character. Due to this, the Austrian school introduces its own concept of entrepreneur, that can change social and cultural standards without interventionism. In that sense, Coyne and Boettke (2009) made a great effort in elaborating an entrepreneurial theory of social and cultural change, where they adapt the Austrian economic approach about entrepreneurship and economic calculation, in which social change is only feasible if it is performed by entrepreneurs but not by governments and political agents.

Although oyne and Boettke (2009) state that only entrepreneurs can attain the social and cultural change, and that government cannot due to difficulties in estimating what they call reputation capital, they only focus on democracies and only adapt one concrete Austrian idea about the economic calculation debate (the Misesian one) to their argumentation. To make it a more robust theory, that can reject any political action of any system, not only democracies, we will introduce the thorough theory about entrepreneurship and economic calculation developed by Huerta de Soto (2010), which mix the Misesian argument and the Hayekian reasoning about the impossibility of socialism, grounded in an exhaustive theory of the entrepreneurial knowledge.

Our contribution will reinforce the current Austrian entrepreneurial theory of social and cultural change by underlining the impossibility of any political action, because of the very nature of the entrepreneurial knowledge necessary to the whole social process. Then, further research can delve into this idea and investigate the creation and transmission of such entrepreneurial knowledge, as well as study cases in which entrepreneurial action has succeeded while the government has failed in the same goal.

\footnotetext{
${ }^{1}$ Many other Austrian scholars have dealt with the question of political entrepreneurship. Klein (2010) addresses the contributions of Baumol (1990) and Holcombe (2002) when they asserted: "entrepreneurship may be socially harmful if it takes the form of rent-seeking, attempts to influence governments to redistribute income in a way that consumes resources and brings about a social loss" (KLEIN, 2010, p.85). Also, Coyne et al. (2010) define political entrepreneur as the one that makes "use of the political apparatus to secure rents at the expense of broader social well being" (p. 340).
} 


\section{The entrepreneurial theory of social and cultural change}

Professors Christopher Coyne and Peter Boettke devote one paper to elaborate a theory of social and cultural change based on entrepreneurship (COYNE; BOETTKE, 2009). They demonstrate, theoretically and empirically, how entrepreneurs can attain social and cultural changes, and by contrast, how public agents cannot. They do so by transferring the Austrian theory of economic calculation and entrepreneurship to the non-market and public spheres.

Firstly, they introduce their work explaining the concept of focal points, developed by Schelling (1960), and then stress the importance of them in their theory. These focal points are rules used by individuals to coordinate without full information. So, their "notion of social and cultural change involves shifting the formal and informal institutions which are currently focal" (COYNE; BOETTKE, 2009, p. 78). Moreover, in order to attain social change, they state the need for creating ${ }^{2}$ new focal points and common knowledge to expand this focal point on a larger scale. In other words, they want to "focus on how new conjectures are actively created and how common knowledge is created around those conjectures" (COYNE; BOETTKE, 2009, p. 78) by the entrepreneur. Briefly, they want to study how the entrepreneur changes culture and society by creating and shifting focal points (institutions) and common knowledge.

After that, they highlight the centrality and relevance of the entrepreneur by using theoretical concepts of Mises (1998) and Kirzner (1973) about entrepreneurship. Hence, by the Kirznerian branch, they talk about alertness and how entrepreneurs can discover unrecognized opportunities $^{3}$ in the market; and like Mises (1998) asserted that the entrepreneur is the driving force of the market economy, Coyne and Boettke (2009, p. 79) state that "the entrepreneur is also the driver of social and cultural change".

Having established some initial premises, parallel to the Austrian market theory, they describe the theories of entrepreneurship and economic calculation. In the market setting, the entrepreneur is devoted to taking advantage of market opportunities that are consequences of the gap between the value of resources and its price in a world of imperfect information and uncertainty. The entrepreneur is continuously allocating resources to their most highly valued uses; thus, he needs one disciplinary mechanism that can indicate if he is acting well or not. This mechanism is that of prices and profit/loss. First, prices convey knowledge to market participants, and so, the entrepreneur can be alert to profitable opportunities and make the economic calculation. Secondly, derived from the prices, the signal of profit/loss will serve to signal to the entrepreneur whether he has to keep allocating resources in one activity or, on the contrary, has to stop this erroneous activity and allocate these resources in other demanded activities (COYNE; BOETTKE, 2009).

Coyne and Boettke (2009) continue explaining their theses by transferring the theory in the market setting to the non-market and political sphere. Then, they discover one disciplinary

\footnotetext{
${ }^{2}$ The verb create will be a crucial concept in our analysis and contributions on the Coyne's and Boettke's theory.

${ }^{3}$ Kirznerian concepts that explain the main characteristic of the entrepreneur, that is, their ability to alert and take advantage of profitable opportunities in the market (KIRZNER, 1993).
} 
mechanism in the non-market setting: the reputation capital. That is to say, when people are interacting in face-to-face civic interactions -voluntary relations-, they can "undertake an activity in a non-market setting... [then] the outcome will impact how others view him" (p.82). Therefore, if others approve of his activity, he will have his reputation capital maintained or increased. And, conversely, if others disapprove of his action, he will have his reputation capital decreased. However, as the authors underline, it is necessary for the effectiveness of this mechanism that people have "intricate knowledge of the trustworthiness of the acting entrepreneur" (p. 82). Plus, this kind of knowledge is only available in small social networks, so entrepreneurship in the non-market sphere is a local phenomenon that depends on the span of control of people. Furthermore, they point out how, after these first local spheres, the social change can be spread to larger areas.

Unlike in the non-market realm, both professors prove how there is no such effective disciplinary mechanism in the political sphere as in the former one. They treat democracies, where the voting mechanism could seem like a disciplinary mechanism, but precisely, they demonstrate why this democratic mechanism is not effective. This is because "the voting mechanism is governed by the logic of concentrated benefits and dispersed costs. The interaction in democratic politics is characterized by rationally ignorant voters, specially interested voters, and vote-seeking politicians" (p.85). From the rationally ignorant voter theory is deduced that people need to face many costs by acquiring enough knowledge to correctly vote, in comparison with the benefits that voting will report. Therefore, people will not vote for discipline politicians; only well-organized groups will do; so, politicians will concentrate benefits and decisions on these organized groups and will disperse costs among the rest of society. Moreover, they highlight the lack of face-to-face based on willingness, since government turns to employ coercion. It is very difficult that social and cultural changes are driven by public agents shifting and creating focal points to adjust the values and preferences of individuals in society.

Our contributions are committed to reinforcing the argument in favor of entrepreneurship by demonstrating the impossibility of attaining the social and cultural change by political and government actions. We will transfer the Austrian economic theory of economic calculation too, in this case, the new contributions made by professor Huerta de Soto (2010), to make the entrepreneurial theory of social and cultural change more vigorous before the critiques of interventionists.

\section{Theory of economic calculation: Huerta de Soto's contribution}

Two arguments against the economic and social success in socialism are clearly identified in the Austrian School. One was made by Mises (1951) and another by Hayek (1948). The former is focused on an algebraic or computational argument (HUERTA DE SOTO, 2010), since in socialism there is neither market, nor private property, and free exchange of means of production, it is impossible that prices of those capital goods can emerge; thus, the economic calculation is not possible. Before coming to this conclusion, Mises (2009) treated the existence 
of two different worlds: one subjective world of internal individual valuations (ordinal) and another external world of market prices, set in monetary units (cardinal). The bridge between them is interpersonal exchange, in which the price is revealed. Hence, if there is no freedom to exchange, such a bridge will not exist, prices will not emerge, and economic calculation will be impossible. Hayek (1948), on his behalf, built up his critique against central planning, focusing on an epistemological argument (HUERTA DE SOTO, 2010). For him, it is impossible that a central authority can concentrate all the dispersed knowledge that is in the market and organize the entire society. There is such an immensity of knowledge decentralized among society that it is not feasible that the government can get all of the necessary information to plan the social and economic relations.

These two theses have usually been considered separately. Nevertheless, professor Huerta de Soto (2010) has connected both postures to create a more consistent theory against socialism, even stressing that both theories are two sides of the same coin. Huerta de Soto (2010) commences his reasoning by describing human action and entrepreneurship. Therefore, he states that humans have subjective means and ends, that is, knowledge and information that change. Thus, humans act in pursuing their subjective ends, and, in order to achieve them, they have to coordinate with others. In coordinating with others, they continuously discover, create, and transmit knowledge and information to the social corpus. However, this knowledge is not a scientific nor objective one; instead, it is subjective, practical and exclusive; dispersed throughout the minds of all men; tacit, so it is inexpressible in words; created ex nihilo; and can only be transmitted unconsciously, through complex social processes.

More concretely, in economic relations, people act entrepreneurially following their means and ends, and, when coordinating, they transmit this subjective knowledge to the market in the form of prices. This knowledge is perceived by the entire market through prices, so this allows for economic calculation and coordination of acting plans and the fulfillment of people's ends. This understanding of human action and the social processes leads Huerta de Soto (2010, p. 27) to conclude that: "without the exercise of entrepreneurship, the information necessary for the actors to properly calculate or estimate the value of each alternative course of action is not created. In brief, without entrepreneurship, economic calculation is impossible". Hence, given that socialism, as Huerta de Soto (2010, p. 3) says, "is any system of institutional aggression on the free exercise of human action or entrepreneurship", in it, the economic calculation will not be possible.

As it has been proved, Huerta de Soto (2010) connects the Hayekian and the Misesian ${ }^{4}$ arguments about the impossibility of economic calculation in socialism. In essence, "it is impossible to make any economic calculation, or the corresponding preliminary judgments, if the necessary information, in the form of market prices, is unavailable. Plus, it is the free exercise of entrepreneurship, which constantly results in the creation of such information"

\footnotetext{
${ }^{4}$ Huerta de Soto (2010) even says that Mises already identified and combined both arguments, the epistemological and computational ones, by reproducing Mises' (1951) words: "It is the speculative capitalists who create the data to which he has to adjust his business and which therefore gives direction to his trading operation" (p. 140).
} 
(p. 108). Moreover, regarding the problem of knowledge, Huerta de Soto (2010) sets additional ideas against socialism. He asserts that socialism is an intellectual error since the governing body cannot gather all the information necessary to plan social coordination due to several causes. First, the government cannot assimilate the enormous volume of knowledge dispersed in society. Second, as this information is tacit, it cannot be articulated nor transmitted to the governing body. Third, information that has not been created yet by the entrepreneurs, cannot be transmitted. Fourth, coaction prevents entrepreneurs from discovering and creating the knowledge essential to the coordination of society.

In summary, the work of Huerta de Soto (2010) includes a complete understanding of human action, entrepreneurship, kinds of knowledge, and social processes. His dynamic argument against socialism is epistemological and computational; the government cannot create nor process the dispersed, tacit, subjective knowledge necessary to plan society or to make the economic calculation. That knowledge can only be discovered and created by the entrepreneur, in an environment of freedom and private property.

\section{A theoretical contribution based on Huerta de Soto's idea}

Coyne's and Boettke's (2009) theory is based on the computational argument developed by Mises. They identify a social mechanism, reputation capital, that allows for rational calculation in the case of social entrepreneurship. By contrast, they do not distinguish such an effective mechanism for rational calculation in the case of political agents. Nevertheless, they only analyze the problem with one concrete mechanism, voting, in a determined system, democracy. To that, interventionists can suggest other mechanisms different from voting, including, for instance, the use of new technologies ${ }^{5}$. Thus, by applying the concepts elaborated by Huerta de Soto (2010), this entrepreneurial theory of social and cultural change can be enhanced to reinforce its critique of government intervention and its defense of the entrepreneur as the driving force of all social phenomena.

At first, it is very pertinent to analyze how professors Coyne and Boettke devise their idea. As well as Huerta de Soto (2010), Coyne and Boettke (2009) give much importance to the role of knowledge. They talk about knowledge on several occasions. First, as we saw in the introduction, they present the concept of focal points, and thus, how entrepreneurs will act to shift or create these focal points. However, to attain the social change, they underline the need for two elements: the creation of (1) new focal points and (2) common knowledge. Here it is the first connection between both theories: knowledge is what the entrepreneur creates and what causes social change, as in Huerta de Soto's (2010) theory. Second, when both authors introduce the disciplinary mechanism of reputation capital, they specify that this mechanism will only

\footnotetext{
${ }^{5}$ In fact, there is a field in researching devoted to estimate and model reputation in social networks. See for example, the work of Sabater-Mir and Sierra (2002), in which they also remark the point that, in large societies, it is very difficult to obtain the information about direct interactions due to the scarcity of those aforementioned.
} 
be effective if people have intricate knowledge about the entrepreneur, so this mechanism is limited to local phenomena and small social networks.

In their work, they establish that the goal is to get the reputation capital that allows individuals to allocate their efforts to change certain facts. However, in order to make the rational estimation of reputation capital, some kinds of knowledge are previously required. Besides the two types of knowledge that Coyne and Boettke (2009) refer, we can add two additional types: focal points and the specific idea introduced by the entrepreneur. To that extent, these four kinds of knowledge can be studied by following the features of entrepreneurial knowledge studied by Huerta de Soto (2010).

The entrepreneur's idea: it is the new concept that the entrepreneur is trying to introduce in society. Once introduced, this idea changes the available information in society. As such, this knowledge fits every feature of Huerta de Soto's (2010) theory. So, it is subjective and practical since it cannot be represented in a formal or scientific manner; instead, it is created by the subject in his particular circumstances and what he considers regarding his preferences and values. By knowing his context, the actor can conceive many ideas that can attain social change according to his ends. He does not think about the social process in scientific terms, but he thinks about the idea by observing his environment and in pursuit of his ends. At the same time, this practical knowledge is exclusive and dispersed. Each person lives specific situations and thinks in a concrete and individual manner; definitely, each person has an unrepeatable vocation, and because of that, the knowledge he creates is exclusive to them and unique. Hence, this information is not available, given nor stored; conversely, it is dispersed throughout the minds of every human being, and it is unique to each one of them. Furthermore, Huerta de Soto (2010) reminds us that practical knowledge is mainly tacit, so it cannot be articulated. Precisely, the new subjective, practical, exclusive, dispersed and tacit idea is created ex nihilo by the subject concerning his ends and circumstances and can only be transmitted through very complex social processes. The entrepreneur is who only knows better than anyone what he sees, what he wants, and what he thinks.

Focal point: by treating the transmission of the new idea -a specific kind of knowledge-, the theory sets that this new information can only be transmitted through very complex social processes. These social processes are compounded by many institutions, and, to start, we can define an institution as "a repetitive pattern, rule or model of conduct" (HUERTA DE SOTO, 2010, p.44). Coyne's and Boettke's (2009, p. 78) entrepreneurial theory goes in the same way, considering that their "notion of social and cultural change involves shifting the formal and informal institutions which are currently focal". As Huerta de Soto (2010), Coyne and Boettke (2009) expound that the entrepreneur inserts his new idea through social institutions, by shifting or creating them. The Austrian School of economics has developed a theory of institutions of excellent quality. According to it, institutions emerge in spontaneous order and in an evolutive process of trial and error. These two previous terms mean that institutions are complex processes that are not designed by the human mind, but derived from human actions, in a dynamic world where these institutions are continuously changing (HAYEK, 1998). People do not theorize about these complex social processes and do not think of designing better 
social institutions. Instead, they unconsciously follow institutions and can unintentionally change them by their individual and subjective acting. Hence, due to its very nature, focal points -social institutions- consist of subjective, practical, and tacit information that emerges spontaneously and is dispersed throughout many people.

Common knowledge: Coyne and Boettke (2009, p.78) argue that "the process of change entails not just creating a new focal point but also developing common knowledge to make it focal on a larger scale". The entrepreneur has to create or shift focal points, as well as create common knowledge. Coyne and Boettke (2009) mention one noteworthy form of common knowledge; advertising. Also, Huerta de Soto (2010) addresses different varieties of common knowledge; in concrete, he alludes to language and financial and cost accounting. About the latter, he remarks that "entrepreneurs use it as a guide of their actions and which consists simply of practical knowledge or techniques (...), even though most entrepreneurs are unable to formulate a scientific theory of accounting (...)" (p. 23). It is the same with advertising. Thus, the common knowledge that entrepreneurs develop to create convergence around focal points is composed of practical and subjective knowledge; each entrepreneur creates it, so it is dispersed and exclusive as well.

Intricate knowledge: it is the knowledge necessary to make the disciplinary mechanism of reputation capital effective. Since the reputation market depends on direct interactions, the estimation of reputation capital is a local phenomenon that relies on people's span of control (COYNE; BOETTKE, 2009). This is because reputation capital is very subjective information that cannot be transformed into objective information. In the market setting, preferences are transformed into prices, which is an objective knowledge that can be transmitted and processed very easy. However, in the non-market setting, there is no objective knowledge as prices, but very subjective, practical, and exclusive knowledge about the others. So, in order to create, transmit, or process this information that allows for estimation on reputation capital, people work in small social networks, where they need intricate knowledge about their closest people. This is a very tacit and exclusive knowledge because it is tough to articulate, and very personal to each individual. It is very difficult to transmit and articulate this form of knowledge, even among very close individuals in their own span of control'.

If noticed, these kinds of knowledge fit the features described by Huerta de Soto (2010); it is knowledge created by entrepreneurs and individuals, so it is not objective, scientific nor transmissible, but subjective, practical, exclusive to the individual, dispersed throughout people's

\footnotetext{
${ }^{6}$ Transmission of information in the market is done via prices. Coyne and Boettke (2009) notice that this is not easy in the non-market spheres. They say that their mechanism is a proxy of the transmission of knowledge in the market via prices, which does not work with the same precision. However, they explain very coherently how entrepreneurs convey knowledge to society about social changes. Because of that, they use the idea of focal points, which are social institutions used to spread information about social and cultural changes. They talk about common knowledge, like advertising, to transmit knowledge. As well, information about social and cultural changes can be transmitted trough prices and the mechanism of profit/loss. Many products can be suddenly demanded due to its social and cultural features or many enterprises can increase profits thanks to a desirable action that influences cultural and social change. In these cases, prices and profits will be marking actions that are desirable to social change.
} 
minds, tacit, inarticulable and created ex nihilo. Such information is created in a decentralized way and is what allows for rational calculation and social coordination.

Coyne and Boettke (2009) explain, very similar to Huerta de Soto (2010), how the social process works. Individuals, acting as entrepreneurs, shift and create focal points and common knowledge in order to introduce new social and cultural changes. By doing so, they are creating and transmitting a sort of knowledge that has to be previously approved by their circle of close relationships before it is expanded to the rest of society. At the same time, each individual has a reputation capital, that is only known and determined by his closest relationships since it depends on intricate knowledge. Reputation capital will serve as an indicator to allocate efforts, but the estimation on this reputation capital fundamentally needs the new entrepreneurial idea, the focal point, the common and the intricate knowledge, that have all the characteristics already studied by Huerta de Soto (2010). In the end, subjective, dispersed, practical, and tacit knowledge is what makes possible, firstly, to introduce changes, and secondly, to allocate endeavors.

By this interpretation of social process and knowledge, we can build up a much more vigorous and consistent argument against interventionism. Coyne and Boettke (2009) focus on the computational argument to refute interventionism's effectiveness and the precise mechanism of voting within democracies. Even so, we can broaden their argument for any form of intervention or governmental mechanism.

Regarding the most extreme sample of planning, socialism, in which the government tries to design the complete social and cultural change, many Austrians have pointed out how it is not possible to plan the entire society and social order. Mises (1998, p.188) wrote: "any given social order was thought out and designed before it could be realized. This temporal and logical precedence of the ideological factor does not imply the proposition that people draft a complete plan of a social system as the utopians do" and Hayek (1992, p.6) asserted: "to understand our civilization, one must appreciate that the extended order resulted not from human design or intention but spontaneously". The same occurs in all other forms of intervention. Any mechanism that the government can try to attain social change will be ineffective and will fail, from the most interventionist measures to the least interventionist ones. This is due to an epistemological problem that, in consequence, ends to be a computational problem since the government cannot estimate the reputation capital. It is the same argument that Huerta de Soto (2010) dedicates to refute any form of interventionism.

By understanding that knowledge is the elemental part of the social process, and the characteristic of such knowledge, we can conclude that any political mechanism will fail to achieve social change. It is a knowledge emerged spontaneously, dispersed throughout individuals' minds, exclusive to and created by them. Only entrepreneurs can discover, create, and transmit this information that makes all social phenomena possible. The government cannot create such knowledge, neither gather nor transmit it. Moreover, the government prevents the entrepreneur from creating and transmitting this information. The only way possible for this knowledge to be created is by means of entrepreneurship; hence, entrepreneurs require freedom to act and interact with others. Government, in essence, limits liberties considering 
that it only resorts to coercion and violence. So, the government cannot transmit nor create adequate knowledge and cannot calculate reputation capital in any way ${ }^{7}$. Furthermore, its action impedes the creation of intricate knowledge and individual estimations on reputation capital by limiting interactions between individuals.

Additionally, the State has indirectly destroyed social bonds and communities, by the creation, for instance, of the welfare state. Now, individuals trust less in others and more in government, which leads to the atomization of society (HOPPE, 2001). This circumstance directly goes against a central required premise to the rational calculation of reputation capital: the intricate knowledge, only available in small social networks, where people know enough about the other. If the government destroys and harms social networks, knowledge necessary to the estimation of reputation capital cannot emerge. Only when people are free to interact with others, and in consequence, a robust social fabric exists, can intricate knowledge emerge, and the rational estimation of reputation capital will take place. No public policies or limitations are needed; the very existence of the State harms people's interactions, destroys the social fabric, and prevents from estimating reputation capital, necessary to social dynamics and changes.

Assuming that the function of political entrepreneurs is "the direction of coercively obtained resources by the state toward processes of production which would not otherwise have taken place" (MCCAFFREY; SALERNO, 2011, p. 553), we can come to the same conclusion. If political entrepreneurs use the coercive and violent tools of the State ${ }^{8}$, they will destroy social relationships and will distort the mechanism of reputation capital and the creation of entrepreneurial knowledge. With their action, the process of social and cultural change becomes less dynamic, ineffective, and will harm the social fabric.

\section{Conclusion}

The entrepreneurial theory of Coyne and Boettke (2009) is a very good scheme to understand how social and cultural change works similar to the economic process. In fact, they address the sociological and cultural processes at the light of the economic theory of the Austrian School of Economics. Hence, they adopt every theoretical implication, even affirming that political agents cannot effectively achieve social and cultural changes. This is an excellent point, in defense of the entrepreneur as the driving force of the social process, and against the political intervention. Nonetheless, their argument can be reinforced against any form of interventionism. For this purpose, the theoretical contributions developed by Huerta de Soto (2010) about the impossibility of socialism, based on a dynamic argument,

\footnotetext{
${ }^{7}$ Social and cultural changes in quasi-socialist countries can occur. However, the government will not encourage a socially desirable change, chosen by individuals, but an arbitrary idea or value. This will have negative consequences, such as the decomposition of social bonds, what directly affects and harms relationships and intricate knowledge, essential to estimations in reputation capital. Consequently, a socialist society will be less dynamic and will experience less social and cultural changes than a free society, since information cannot be created nor transmitted.
}

${ }^{8}$ Otherwise they will not be political entrepreneurs, but simply entrepreneurs or social entrepreneurs. 
prove that it is not possible for the government to attain social and cultural changes due to epistemological problems.

In short, it is impossible for political agents to achieve social and cultural changes because they cannot create, transmit nor process sufficient knowledge to estimate reputation capital, which is the central computational part of the rational estimation that people do in their social relations. Only entrepreneurs in a free society can create and transmit the relevant information to the social change, what makes it possible to estimate reputation capital and activate the complete mechanism of social transformation. Governments cannot attain social and cultural changes in any way, only entrepreneurs in a free society can do it.

\section{References}

BAUMOL, William J. Entrepreneurship: Productive, Unproductive and Destructive. The Journal of Political Economy, v. 98, n. 5, 1990.

COYNE, Christopher; BOETTKE, Peter J. An Entrepreneurial Theory of Social and Cultural Change. In: PÉREZDÍAZ, Victor. Markets and Civil Society: The European Experience in Comparative Perspective. New York: Berghahn Books, 2009.

COYNE, Christopher; SOBEL, Russell S; DOVE, John A. The non-productive entrepreneurial process. Review of Austrian Economics, v. 23, 2010.

HAYEK, Friedrich August von. Individualism and Economic Order. Chicago: The University of Chicago Press, 1948.

HAYEK, Friedrich August von. Law, Legislation and Liberty: A new statement of the liberal principles of justice and political economy. London: Routledge, 1998.

HAYEK, Friedrich August von. The Fatal Conceit: The Errors of Socialism. London: Routledge, 1992.

HOLCOMBE, Randall G. Political entrepreneurship and the democratic allocation of economic resources. Review of Austrian Economics, v. 15, 2002.

HOPPE, Hans-Hernmann. Democracy: the God that Failed. New Brunswick: Transaction Publishers, 2001.

HUERTA DE SOTO, Jesús. Socialism, Economic Calculation and Entrepreneurship. Cheltenham: Edward Elgar, 2010.

KIRZNER, Israel M. Competition and Entrepreneurship. Chicago: The University of Chicago Press, 1973.

KLEIN, Peter G. The Capitalist and the Entrepreneur: Essays on Organizations and Markets. Auburn: The Ludwig von Mises Institute, 2010.

MCCAFFREY, Matthew; SALERNO, Joseph T. A Theory of Political Entrepreneurship. Modern Economy. v. $2,2011$.

MISES, Ludwig von. Human Action: A Treatise on Economics. Auburn: The Ludwig von Mises Institute, 1998. MISES, Ludwig von. Socialism: an Economic and Sociological Analysis. New Haven: Yale University Press, 1951. 
MISES, Ludwig von. The Theory of Money and Credit. Auburn: The Ludwig von Mises Institute, 2009.

SABATER-MIR, Jordi; SIERRA, Carles. Reputation and social network analysis in multi-agent systems. Proceedings of the International Conference on Autonomous Agents, p.475-482, 2002.

SCHELLING, Thomas C. The Strategy of Conflict. New York: Oxford University Press, 1960.

RECIVED: $5 / 1 / 2020$

APPROVED: $3 / 3 / 2020$ 